\title{
El aula virtual y la olla exprés
}

Teresa I. Fortoul

\section{Resumen}

No es lo mismo emplear la computadora como editor de textos que como herramienta para armar un aula para un curso en línea. Además, durante esta pandemia, me he dado cuenta de que, a pesar de las diferencias generacionales, siempre hay algo que compartir entre madre e hija, como emplear la olla exprés.

Palabras clave: tecnología, aulas virtuales, cursos en línea, olla exprés.

\section{A VIRTUAL CLASSROOM AND a PRESSURE COOKER}

\section{Abstract}

Using a computer as a text editor is not the same as using it as a tool for developing a classroom for an online course. Besides, during this pandemic I have realized that, despite generational differences, there is always something to be shared between mother and daughter, like using a pressure cooker.

Keywords: technology, virtual classroom, online courses, pressure cooker.

Recepción: 09/10/2020. Aprobación: 1/12/2020. Dol: http://doi.org/10.22201/cuaieed.16076079e.2021.22.1.5 
Médico cirujano, neumóloga, maestra y doctora en Ciencias. Profesora de carrera de la Facultad de Medicina, de la Universidad Nacional Autónoma de México (UnAM). Para ella, escribir por gusto es un pasatiempo, la divulgación de la ciencia y el arte, un placer. ajustó con el empleo del correo y logramos terminar el semestre sin novedad.

Mi encuentro con la tecnología no fue suave. El trancazo lo sentí cuando enfrenté el hecho de que reiniciaríamos clases y que ¡todo sería en línea! Era tal mi incertidumbre que me paralicé. Tomé los cursos ofrecidos, los cuales me brindaron cierta seguridad para enfrentar lo que venía. Sin saber bien qué plataforma emplearía para las clases, recurrí a mi hija, que ya tenía experiencia en eso.

Muy decidida, pues, inicié el montaje de mi aula, con cursos y todo. Hubo un momento en que dudé si podía plasmar en un curso en línea eso que di por tantos años en un aula presencial. Cada intento era un regreso al inicio, como si me hubiera metido en un laberinto del que no podía salir. Un día mi hija me vio tan bloqueada que me dijo:

-Ma, ya no le des vueltas y siéntate a armar tu curso. Me preocupa que no avanzas. Deja de procrastinar, yo te ayudo. 
Con toda la paciencia del mundo, se sentó junto a mí y me fue guiando para armar la dichosa aula. Poco a poco fui avanzando e introduciendo los materiales para cada tema. Cada paso era un reto que intentaba resolver sola, pero siempre había un temor escondido y absurdo de que todo se borraría y tendría que volver a empezar. Así transcurrieron las semanas previas al inicio de los cursos, en las que pude apreciar el trabajo que mi hija y yo realizamos juntas durante la pandemia. Dos generaciones, madre e hija, compartiendo vivencias, saberes y experiencias.

Puedo decir que, en este intercambio de conocimientos, ella aprendió a usar la olla exprés y a hacer arroz, y yo a emplear las herramientas necesarias para transformar mi asignatura presencial en un aula virtual. Ella aprendió a perderle el miedo a que explotara la olla exprés, y yo a que lo hiciera la computadora.

Sigo en proceso de aprendizaje, pero si algo nuevo ocurre que requiere de mi experta en esa dichosa aula, sólo lanzo un grito de auxilio:

—iHijitaaaaa!

\section{Cómo citar este artículo}

* Fortoul, Teresa I. (2021, enero-febrero). El aula virtual y la olla exprés. Revista Digital Universitaria (RDU), 22(1). Dol: http://doi.org/10.22201/ cuaieed.16076079e.2021.22.1.5 